\title{
STATE OF EMERGENCY FOR REASONS OF NATIONAL SECURITY
}

DOI:10.47743/rdc-2020-2-0003

\author{
Andrei-Nicolae POPA \\ Faculty of Law, University of Bucharest
}

\section{Abstract}

This article begins from the hypothesis that the state of emergency should be able to be established only for reasons of national security. The main argument is that a state of emergency should be established for causes of an exceptional nature and other than those for which the exercise of fundamental rights and freedoms is currently restricted. The content of this article demonstrates that the state of emergency is a defensive- offensive act through which the state temporarily suspends some legal institutions, replacing them with others, to protect the existence of the state itself (seen as population, territory, sovereignty), this being the supreme value. protected by such measures.

Keywords: state of emergency; national security; state of emergency; calamity; pandemic

\section{Introduction}

With the establishment of the state of emergency on March 16, 2020, by the Decree of the President of Romania no. 195/2020, public opinion and legal professionals have been constantly concerned about the regulations that limit the exercise of fundamental rights and freedoms in the context of the state of emergency. They were subject to the control of both the Constitutional Court of Romania (CCR) and the courts of law. However, it is easy to see that there was no debate on the causes for which the state of emergency can be established according to art. 93 of the Constitution.

In this article, we address the state of emergency from the perspective of the causes for which it can be established. The research hypothesis is that, according to the legal physiognomy of the Romanian Constitution, the state of emergency should be able to be established only for reasons of national security. In developing the arguments, we start from the premise that the state of emergency is an exceptional measure that exceeds, by nature, legal regime and purpose, the general framework for restricting the exercise of fundamental rights and freedoms. Therefore, the causes of its establishment should be well delimited and different from the ordinary ones of restriction provided by art. 53 and to aim the protection of values and rights to which the very existence and good development of the state and its population are linked. 
The study presents a history of the provisions of the Romanian constitutions regarding the exceptional measures and continues with the current infraconstitutional limits of the state of emergency. Following the line of the research objective, we demonstrate why the state of emergency can be established only for reasons of national security. Finally, we analyze whether the COVID-19 pandemic is a national security issue for which a state of emergency can be established.

\section{Defining concepts}

Before continuing our scientific approach, it is necessary to define and conceptualize the terms commonly used in the paper: exceptional state, state of necessity, state of emergency, national security.

When referring to an exceptional state, we cannot aim at the establishment of arbitrariness or the lack of legal regulation. The doctrine ${ }^{1}$ considers that, from a legal point of view, the saying "necessity has no law" is rejected. The same doctrine stresses that, if the state of emergency denies or ignores entirely the legal exception provided by it by the common law, not to mention a state of exception but by arbitrariness or denial of the common law as we know it. In essence, for an exceptional "legal" situation, it is necessary that the normative system that establishes and regulates it provides: (i) criteria for identifying (de facto) exceptional situations, (ii) the rules applicable in such circumstances, (iii) the powers that may be activated in such cases, and (iv) control and balance to prevent abuse and use arbitrary "exceptional state" powers by the government. This means, in essence, that a comprehensive, coherent and effective regulatory system must provide for the legal regime of emergencies, which are a subcategory of exceptional states.

In opposition to modern doctrine, for Carl Schmitt, the state of emergency has the character of a heuristic principle: "The exception is more interesting than the normal case. The normal case proves nothing, the exception is the one that proves everything. The exception does not only confirm the rule, in fact the rule only exists because of the exception. As an exception, the force of real life breaks the pattern of a mechanic frozen in repetitions"2. There are also modern authors, such as Giorgio Agamben, who trace the concept of "state of emergency" (Ausnahmezustand) used by Carl Schmitt in justitium and auctoritas romane ${ }^{3}$. Agamben's text, "State of Exception" investigates the rise of power by governments, which they use in times of supposed crisis. In a state of emergency, Agamben refers, in fact, to states of emergency, in which constitutional rights can be diminished, replaced and rejected, in the process of

${ }^{1}$ E.S. Tănăsescu, L'etat d'exception, nouveau régime de droit commun des droits et libertés?, 11.09.2020 - https://dice.univ-amu.fr/sites/dice.univ-amu.fr/files/article/rapport_tr_2020.pdf; accessed on 11.02.2021.

${ }^{2}$ C. Schmitt, Teologie politică, Gallimard, Paris, 1988, pp. 53-55.

3 G. Agamben, State of exception, University of Chicago Press, Chicago, 2005, Cap. 6. 
claiming this extension of power by a government. He argues that such states are the perfect pretext for the endless continuation of the exception that violates the rule. Such a state is likely to annihilate the idea of the state of law and the order of law.

A distinction must be made between the notion of "exceptional situation" and "extraordinary situation". From the etymological point of view ${ }^{4}$, the first refers to the formation of an exception from the usual, an exception that is and remains regulated in the order of law that established it. The second is formed beyond or outside the common order or method.

The Romanian Constitution uses the term "exceptional measures" in Article 93, which establishes the legal regime of two exceptional states, namely the state of emergency and the state of siege. According to the legislation developing these constitutional provisions (Government Emergency Order no. 1/1999), the state of emergency and the state of siege are "exceptional measures" instituted to counteract the emergence of serious dangers to the defense of the country, national security or constitutional democracy; to prevent, limit and eliminate the consequences of natural disasters. However, the Romanian Constitution also uses the term "extraordinary situation" in the case of legislative delegation, which the Court described as expressing "a high degree of deviation from the ordinary or common and have an objective character, in the sense that their existence does not depend on the will of the Government, which, in such circumstances, is compelled to react promptly in defense of a public interest by way of the emergency order" 5 .

Ellen Kennedy said that there is a confusion between the state of emergency and the state of exception in the current political theory, and that it mainly comes from Schmitt's "Political Theology" because the emphasis on theology hides revolution and democracy as sources for a critical legal theory ${ }^{6}$. Based on the analysis of the works of Honig, Lazar, Negri and Osiel, Kennedy concludes that emergency, depending on its intensity, may be the precursor to the exception? ${ }^{7}$. He also argues that urgency and exception are concepts that begin with the normal and the norm (pre-existing regulation). If it is true that the exception is more interesting than the norm, it is not less true that the exception depends on the norm, in the author's opinion. Neither the emergency (as immediate measures) nor the exception (as an out-of-the-ordinary/common state) should be the usual pretext or leverage to govern, as otherwise it would lead to a practice of government based on a reason for chaos, conflict, permanent disorder.

The state of emergency, according to art. 3 of GEO no. 1/1999, can be established only for two categories of reasons. They take, under another extended name, the reasons for constitutional democracy (former "public order") and national security

\footnotetext{
${ }^{4}$ Available at https://comparewords.com/exceptional/extraordinary, accessed on 13.02.2021.

${ }^{5}$ CCR Decision no. 366/2014, published in the Official Gazette, Part I, no. 644 of September 2, 2014.

${ }^{6}$ E. Kennedy, Emergency and Exception, Review Essay, Political Theory, July 11, 2011, available at: https://journals.sagepub.com/doi/10.1177/0090591711406410, accessed on 24.03.2021; p. 536.

7 Ibidem, p. 546.
} 
(former "state security") from the old constitutional regulations. Thus, the state of emergency can be established either only in the case of "the existence of current serious or imminent dangers on national security or the functioning of constitutional democracy", or in the case of "imminent occurrence or production of calamities that make it necessary to prevent, limit or eliminate, as the case may be, the consequences of disasters". The first category refers, as we will see, to the extended field of national security, including constitutional democracy which is a value protected by national security according to art. 1 of Law no. 51/1991. The second category is related to those disasters, calamities, external events of a natural nature and are not of national security nature, but at most of the size of public order. They are closely related to disasters caused by natural, meteorological, geological phenomena etc. ${ }^{8}$.

The notion of national security includes a legal definition, a doctrinal one and a related jurisprudence. All three sources give rise to extensive discussions on the application of the notion in practice, opening new areas of conflict on the security of some areas (inclusion of some areas in the scope of national security).

Regarding the legal definition of the notion of national security, it is established in art. 1 of Law no. 51/1991 on the national security of Romania, which provides that:

"the national security of Romania is the state of legality, balance and social, economic and political stability necessary for the existence and development of the Romanian national state as a sovereign, unitary, independent and indivisible state, maintaining the rule of law and the climate of exercising unrestricted rights, freedoms and fundamental duties of citizens, according to the democratic principles and norms established by the Constitution".

The legal definition provides as supreme values the legality, balance and social, economic and political stability of the state, taking over, as we can see, the hypothesis of national security established in the majority doctrine of security studies. Then, the definition takes over the fundamental elements that define the Romanian state from art. 1 of the Romanian Constitution. Thus, Romania's national security recognizes the supremacy of the constitutional system and the legal basis of the Romanian state. Romania's national security implies, therefore, a state that guarantees the existence and development of the "identity card" 9 of the state, but also of the state itself. From this perspective we can say, without fear of being wrong, that national security is closely linked to the Constitution and constitutionalism, being designed as a shield to defend the fundamental values, foundation and essence of the Romanian state. Compared to criminal law, which protects only those behaviors that people consider dangerous and qualify as crimes, national security protects the state from any

${ }^{8}$ See the meaning of the notion of "calamity" according to GEO no. 21 of April 15, 2004 on the National Emergency Management System, published in the Official Gazette, Part I, no. 361 of April 26, 2004, and GEO no. 148 of 27 August 2020 for the establishment of a state aid scheme granted to agricultural producers who set up crops in the autumn of 2019, affected by the pedological drought, published in the Official Gazette, Part I, no. 806 of September 2, 2020.

${ }^{9}$ I. Muraru, E.S. Tănăsescu, Articolul 1. Statul roman, in I. Muraru, E.S. Tănăsescu, op. cit. 
behavior that may harm its character declared in the Constitution. Of course, it should be noted that the legal definition is given by a pre-constitutional law, which may not correspond to the real dimension of the constituent to the notion of national security. Moreover, this could even be the cause of the successive decisions of the CCR to redefine and limit the notion of "threat" to national security.

Regarding the doctrinal approach of the notion of "national security", it has several definitions, depending on the school of thought to which it belongs to. All definitions start from the etymology of the word "security", which comes from the Latin "securitas". Securitas, in Roman mythology, is the goddess of security, stability and balance of the Roman state ${ }^{10}$. A first definition of security is found in the Oxford English Dictionary which takes over the mythological origins of the word, defining it as:

"The condition of being protected or not being exposed to danger; feeling of security or freedom, absence of danger"11.

Probably the most well-known and used doctrinal definition of the notion of national security belongs to Arnold Wolfers ${ }^{12}$ who states that:

"Security, in an objective sense, measures the absence of threats to acquired values and, in a subjective sense, the absence of fear that such values can and will be attacked".

The famous political scientist Walter Lippmann ${ }^{13}$, who is also the first author that writes on intelligence, in his book "Public Opinion", states that:

"A nation is safe unless it is in danger of having to sacrifice core values if it wants to avoid war and can, when challenged, maintain them by winning in a war"14.

Another famous author, Michael H.H. Louw ${ }^{15}$, claims that:

"National security includes the traditional defense policy and also the nonmilitary actions of a state, in order to ensure its full survival capacity as a political entity, in order to exert its influence and achieve its domestic and international objectives".

Last but not least, the National Defense College of Canada ${ }^{16}$ claims that:

"National security means maintaining a way of life that is acceptable to citizens and compatible with the legitimate needs and aspirations of others.

\footnotetext{
${ }^{10}$ L. Adkins, R. Adkins, Dictionary of Roman Religion, Oxford Univ Press, 2001, pp. 274-275.

${ }^{11} \mathrm{R}$. Jackson, The safety of the people is the supreme law. Beyond Hobbes but not as far at Kant, in W. Bain, The Empire of Security and the Safety of the People, Routledge, New York, 2006, p. 16.

12 A. Wolfers, National Security' as an Ambiguous Symbol, Political Science Quarterly 67, No. 4, 1952, pp. 481-502.

13 W. Lippmann, Public Opinion, Macmillan, New York, 1922, pp. 369-411, available at https://monoskop.org/ images/b/bf/Lippman_Walter_Public_Opinion.pdf, accessed on 14.03.2021.

14 W. Lippmann, U.S. Foreign Policy, Hamish Hamilton, Londra, 1944.

${ }^{15}$ M.H.H. Louw, National security: A modern approach, Papers presented at the Symposium on national security held at Pretoria, 31 March-1 April 1977.

16 The definition was conceptualized by L.V. Johnson, commander of the National Defense College of Canada.
} 
It includes the absence of armed attacks and coercion, the absence of internal subversion and the erosion of political, economic and social values, which are essential for the quality of life".

In essence, all definitions call for a state of balance, stability and social peace for the preservation of national security and see as threats those dangers of external origins to the state and see vulnerabilities as internal fears and impotence. What is important is that a doctrinal definition of national security will always be influenced by the era in which the author lived, but especially by the school of thought in international relations to which he adheres. And from this point of view, it is necessary to adapt the legal definition from Law no. 51/1991 on Romania's current security needs, taking into account the geopolitical space where it is located and military political alliances to which it belongs.

Regarding the constitutional jurisprudence on national security, it was not a constant one, but fluctuated according to the laws and the correlative political interest that were the object of the constitutionality control. Specifically, in its evolution, the CCR jurisprudence has changed in terms of limiting or extending the area of national security. CCR has operated with several concepts in defining national security, giving the notion different meanings and applicability depending on the field of reference. The jurisprudence of the CCR has developed and clarified the phrase national security, especially by referring to art. 53 of the Romanian Constitution, so from the perspective of restricting the exerting some fundamental rights and freedoms. On the other hand, that of the protection of classified information, CCR analyzed the notion also in relation to the provisions of art. 31. However, we still do not have a constitutional jurisprudence enshrined in art. 119, which should show the constitutional dimension of national security in the light of the CSAT's attributions, implicitly also of the exceptional situations that require the establishment of the state of emergency.

In the CCR Decision no. 872/2010, the Court states that the notion of national security is a constitutional concept and that an element of it is the state of balance and economic stability. The Court also states that: "(1) national security does not only imply military security, or the field of manu militari, but also has a social and economic component; (2) the possibility of restricting exerting certain rights or freedoms provided by art. 53 of the Constitution is a constitutional prerogative distinct from the establishment of exceptional measures (state of emergency or siege) regulated by the provisions of art. 93 of the Constitution (thus, the restriction of the exercise of certain rights may be ordered outside the situations regulated in art. 93 of the Constitution)"17.

In Decision no. $\mathbf{9 1 / 2 0 1 8 ^ { 1 8 }}$, the Court noted that the term "national security" is a plurivalent one and that, from the perspective of art. 53, para. (1) of the Constitution, we can talk about the military, economic, financial, IT, social security of the country.

17 B. Dima, Articolul 119. Consiliul Suprem de Apărare a Țării, par. 14-20, in I. Muraru, E.S. Tănăsescu, op. cit., 2019, pp. 1027-1028.

18 Published in the Official Gazette, Part I no. 348 of April 20, 2018. 


\section{The constitutional history of the state of emergency}

The pre-war constitutions, namely the Development Statute of the Paris Convention of 1984 and the Constitution of 1866, but also the interwar one of 1923, did not know the notion of "state of emergency", i.e. an exceptional state derogating from the common law regime, but which is nevertheless regulated by the legal norm and is part of the legal order.

The Constitution of 1938, at art. 96, knew only the institution of the state of siege, which then referred to a predominantly military threat, but which, perhaps, would have accepted other non-military causes for the onset of the state, that period being known as the "royal dictatorship", Carl Schmitt's ideas not being foreign to the political regime in Bucharest. Likewise, the Constitution of 1948, at art. 33, spoke only about the state of siege, not about the state of emergency.

Since 1952, the Romanian constituent has had a constant concern for the state of emergency. This was found in the $\mathbf{1 9 5 2}$ Constitution in the form of the "state of emergency", which included both the state of siege and the state of emergency. According to art. 37, lit. p), the Presidium of the Grand National Assembly had the attribution that, in the interest of defending the Romanian People's Republic or ensuring public order and state security, should proclaim in some cities or throughout the country the state of emergency. At that time, the Presidium of the Grand National Assembly, although it was part of the legislative power, acted with specific attributions of the executive power, being a collegial body very similar to the institution of the President of our current system with bicephalous executive. It is noted that, since 1952, the Constitution allowed the establishment of this measure only for reasons of national defense, public order and state security. The communist constituent was therefore aware of the notion of national security, for which such a measure is required to restrict even the rights and freedoms in their substance.

Through the Constitution of 1965, the Constituent Assembly replaced the term "exceptional situation" with that of "state of necessity" and shares the attribution of its establishment between the Great National Assembly (art. 43, point 22) and the President of the Socialist Republic of Romania (art. 75, point 14). If the Grand National Assembly had a discretionary right to declare a state of emergency, the President of the Republic could exercise this power only in accordance with the law adopted by the Grand National Assembly and in urgent cases ${ }^{19}$. The two conditions imposed on the president are very similar, at least in theory, to those of today, where the president of the republic is required to establish a state of emergency under the

${ }^{19}$ For example, Decree no. 208/1985 on the establishment of the state of necessity and the militarized regime in the units of the National Energy System, published in the Official Gazette no. 50 of October 18, 1985, or Decree 145/1975 on the establishment of the state of necessity on the territory of the Socialist Republic of Romania, published in the Official Gazette no. 69 of June 4, 1975, were issued by the President of the Republic directly on the basis of the constitutional provisions, not of a law regulating the "state of necessity".

STUDIES AND ARTICLES 
terms of organic law [art. 73, para. (3) letter g)], which establishes the regime and which we will address further. The two texts preserve the reasons for which the state of necessity can be established, namely the defense of the country, public order and state security.

The 1974 amendments do not change the provisions of the 1965 Constitution, further dividing the task of establishing the state of necessity between the Great General Assembly (art. 43, point 21) and the President of the Socialist Republic of Romania (art. 75, point 13), with the corresponding conditions and limits. The same provisions were retained in the form amended in 1986 (art. 43, pt. 22 and art. 75, pt. 14).

The Democratic Constitution of 1991 establishes a new vision of exceptional measures, separating them into three institutions (state of war, state of siege and state of emergency). Compared to the provisions of the previous constitutions, the holder of the establishment of the state of emergency is only the President of Romania, according to art. 93 of the Constitution, which adopts a decree of establishment and requests the Parliament to approve the adopted measure, within 5 days from its adoption. If the Parliament is not in session, it shall be convened by law no later than 48 hours after the establishment of the state of emergency and it shall function throughout their duration. According to the CCR Decision no. 152/2020, the act of the Parliament approving the measure is the order, which may be the exclusive object of the constitutionality control together with the body of the decree establishing the state of emergency ${ }^{20}$, pursuant to art. 146, let. I) of the Constitution and of art. 27 of Law no. 47/1992. In the same decision there is a well-argued competing opinion stating that the content of the President's decree is verified in terms of legality and validity by administrative courts, not by Parliament by amending the Decree or by the Court by reviewing the constitutionality of the decision of approving Parliament ${ }^{21}$.

Regarding the notion of "approval", part of the doctrine considers that the approval act has the validity of an approval and has the following characteristics: "Approval involves only the approval or not of the action; This does not change the nature of the act or the legal regime; Approval adds nothing to the effects of the act; The President is not obliged to execute or persist in the execution of the act neither before nor after approval. The approval does not cover the defects of the decree of establishment; Approval is not only a condition of validity, but also a way of control"22. Another point of view, retained in the competing opinion of Decision no. 152/2020, states that, "in essence, the regulations currently in force show that the President of Romania may decide on the establishment of a state of siege or a state of emergency by a decree that has to be countersigned by the Prime Minister, and the Romanian Parliament may or may not approve this measure. If the Parliament does not approve

\footnotetext{
20 In the same sense, the RCC also ruled in decision no. 152/2020, para. 93.

${ }^{21}$ Idem, para. 2-6 from the concurrent opinion of the judges prof. univ. dr. E.S. Tănăsescu and dr. L.-D. Stanciu.

22 I. Deleanu, Instituții și practici constituționale, Ed. C.H. Beck, Bucharest, 2006, p. 733.
} 
the status quo, the President immediately revokes the decree, and the established measures cease to be valid"23. It was also noted that "The Parliament approves or does not approve the establishment of a state of siege or a state of emergency and does not verify the validity or appropriateness of the decree of the President of Romania for the simple reason that such attributions were given by the Constitution [art. 126 para. (6)] in the jurisdiction of the courts. The Constitutional Court has a competence also established by the Constitution (art. 146) and it does not include the verification of any normative administrative acts of the President of Romania; neither the original nor the derived constituent conferred such attributions to the Romanian constitutional judge"24.

Compared to the Constitutions of 1965, 1974 and 1986, which only implied that there must be a law regulating the legal regime of establishing the state of necessity proclaimed by the President of the Republic, the democratic Constitution of 1991 expressly provided, in art. 72, para. (3), lit. e), that the regime of the state of siege and emergency is adopted by organic law. Professor Bogdan Dima notes that "the decrees of the President issued pursuant to art. 93 and of GEO no. 1/1999 are normative administrative acts that establish a competence of administrative rank for the chief executive, in the sense that he organizes the execution of the provisions of legal rank from GEO no. 1/1999 approved by organic law no. 453/2004 by the Romanian Parliament" 25 .

The revision of the Constitution in 2003 retains exactly the constitutional provisions of 1991 on the state of emergency. Before the review, a Government Emergency Ordinance no. 1/1999 was adopted, regarding the state of siege and the regime of state of emergency, subsequently approved by the Parliament by Law no. 453/2004. Compared to the provisions of the communist constitutions, which limited the establishment of the state of emergency only for reasons of defense, public order and state security, the democratic constitution no longer has such limitations, giving the infra-constitutional legislator the power to establish the causes for the state of emergency. From this situation starts our question of research on constitutional limits of the current state of emergency, asking ourselves legitimately if the Constituent Assembly wanted to preserve the constitutional traditions of the past 70 years or has provided a discretionary right of the legislature to establish what are the causes of the establishment of the state of emergency, causes on the basis of which the President may establish the state of emergency and/or state of siege.

${ }^{23}$ Decision no. 152/2020, para. 1 from the concurrent opinion of the judges prof. univ. dr. E.S. Tănăsescu and dr. L.-D. Stanciu.

${ }^{24}$ Decision no. 152/2020, para. 6 from the concurrent opinion of the judges prof. univ. dr. E.S. Tănăsescu and dr. L.-D. Stanciu.

${ }^{25}$ B. Dima, Care este natura juridică a decretelor Președintelui României emise pentru instituirea și prelungirea stării de urgență?, 17.04.2020, available at: https://www.juridice.ro/680432/care-este-naturajuridica-a-decretelor-presedintelui-romaniei-emise-for-establishing-and-extending-the-state-ofemergency.html, accessed on 25.03.2021.

STUDIES AND ARTICLES 


\section{Establishment of the state of emergency for national security reasons}

It is observed that both the communist constitutions and the current Constitution have created an exceptional state, named differently depending on the era and the political regime, for reasons of national security. Therefore, communist constitutions explicitly mentioned in the constitutional text establishing what they call "state of emergency" or "exceptional state" and the current Constitution allowed the legislator to regulate these cases at an infra-constitutional level by law.

The state of emergency appears in the architecture of the current Constitution of Romania as an institution distinct from that of restricting the exercise of certain fundamental rights and freedoms provided by art. 53. If the exercise of fundamental rights and freedoms can be restricted only by law, to protect national security, (public) order, public health or morals, citizens' rights and freedoms, conduct of criminal investigation (born of public order), prevention of consequences a natural disaster, a disaster or a particularly serious event (which are also related to public order), the exercise of fundamental rights and freedoms may be restricted by the state of emergency, according to law, only for reasons of national security, in case of damaging the functioning of constitutional democracy and that of preventing and combating a calamity.

The state of emergency must be seen as a strong interference in the life of our constitutional democracy, with a much stronger impact and effects than a law adopted under the conditions of art. 53, but which is established precisely for the better protection of fundamental rights ${ }^{26}$ and constitutional institutions. In order to understand the exceptional character of the state of emergency, it is necessary to analyze it by comparison with the "ordinary" system of restricting the exercise of certain rights provided by art. 53 .

A common element of the two institutions is the fact that the restriction of the exercise of rights and the regime regarding the restriction of the exercise of certain rights by the decree establishing the state of emergency is achieved only by law. The term law was interpreted by the doctrine in a narrow sense, namely only by normative act of the Parliament. A part of the doctrine ${ }^{27}$ does not recognize the right of the Government to restrict the exercise of fundamental rights and freedoms by ordinance or emergency ordinance, this competence remaining the sole legislative authority of the country to confer a greater degree of protection to the subjective rights offered by the Constitution. Thus, at least theoretically, the regime of state of

${ }^{26}$ See the reasoning made by the Constitutional Court in Decision no. 797/2018, published in the Official Gazette, Part I, no. 207 of March 15, 2019, which considered that emergency ordinances can achieve a conciliation between several fundamental rights, i.e. it is possible to restrict the exercise of fundamental rights (through GEO) for better protection of other fundamental rights.

27 E.S. Tănăsescu, Art. 53. Restrângerea exercițiului unor drepturi sau al unor libertăți, in I. Muraru, E.S. Tănăsescu, Constituția României. Comentariu pe articole, $2^{\text {nd }}$ edition, C.H. Beck Publishing House, Bucharest, 2019, p. 462. 
emergency and siege could not have been established by GEO no. 1/1999, but by law adopted by the Parliament. In this sense, the CCR also retained by Decision no. $152 / 2020^{28}$.

The state of emergency often appears as a rapid reaction action of a defensive or offensive nature that restricts the exercise of certain rights to protect others. The Constitutional Court held that, for national security, only threats against a community, not a single individual, are relevant (see para. 82 of the CCR Decision no. 91/2018). The question is whether affecting the rights of a community implicitly means damaging only some collective rights or individual ones and if the Court reported in its recital, and the latter distinction. The doctrine of constitutional law ${ }^{29}$ states that collective rights are those that belong to groups or collectivities and refer to the right of people to self-determination, to liberation from colonial yoke, the right to associate in unions, national equality, gender equality etc., i.e. some rights which by its meaning and possibility of exercise resides in belonging to a social group ${ }^{30}$. Thus, we see that the collective rights have a lower degree of extent than the individual ones and that they differ from the meaning that CCR suggested to the notion from Decision no. $91 / 2018$. However, the CCR implies that any kind of Title II rights are collective rights if exercised collectively or, in relation to national security, if the threat concerns a community. This interpretation suggested by the Court is redundant and arbitrary and would greatly limit the scope of threats to national security, blocking the state from taking measures to prevent and combat threats to fundamental rights, whether individual or collective or according to how it affects an individual or a community. We consider that it is not the distinction between individual or collective rights that is relevant for their qualification as being of interest to national security, but their mention as such by law together with acts and deeds directed against all fundamental rights and which may represent threats or vulnerabilities. Mentioning these rights as relevant to national security is important because, otherwise, we would either not be able to apply the state of emergency for national security reasons due to lack of clarity and conceptual framing of its boundaries, or we could arbitrarily introduce any issue as being of interest to national security and thus to establish, on its basis, the state of emergency. A similar situation can be said that is applicable to the notions of constitutional order because it encompasses the state of law, the separation and

\footnotetext{
${ }^{28}$ Decision no. 152/2020, published in the Official Gazette, Part I, no. 387 of 13.05.2020, para.116. "Or, taking into account all these arguments, the Court notes that, incidentally, the normative act with such an object of regulation affects both fundamental rights and freedoms of citizens and fundamental state institutions, falling within the scope of the prohibition provided by art. 115 para. (6) of the Constitution. Thus, the Court finds that the legal regime of the state of siege and the state of emergency, in the current constitutional framework, can be regulated only by a law, as a formal act of the Parliament, adopted in compliance with the provisions of art. 73 para. (3) lit. g) of the Constitution, in the regime of organic law".

${ }^{29}$ I. Muraru, E.S. Tănăsescu, Drept constituţional și instituții politice, $15^{\text {th }}$ edition, vol. I, C.H. Beck Publishing House, Bucharest, 2016, para. 188.

${ }^{30}$ I. Muraru, Gh. Iancu, Drepturile, libertăţile și îndatoririle constituţionale, Institutul Român pentru Drepturile Omului, Bucharest, 1992, p. 10.
}

STUDIES AND ARTICLES 
balance of powers, political pluralism or the system of protection system of human rights, so that its generous meaning now allows the establishment of the state of emergency for any cause that is circumscribed to the elements that form the constitutional democracy. In this regard, a public health problem would circumscribe to the subcategory of protection of the fundamental right to health care, so to the protection of constitutional democracy. Also, a protest that is contrary to public order could be a reason for establishing a state of emergency.

Looking at the origin of this exceptional state, we note that in the past, both in the interwar period (when it was called "exceptional situation") and in the communist one (when it was called "state of emergency"), it partially suspended even the prescriptions of the Constitution, i.e. the substance of the right ${ }^{31}$. In comparison, the current restriction of the exercise of some fundamental rights and freedoms can operate only for one of the exhaustive hypotheses listed by art. 53 and is established through a slower process ${ }^{32}$. At the same time, even in the situation of establishing a state of emergency, only the exercise of rights is affected, not their substance, the rules of the state of law remaining in force. Better yet, the Constitution limits the possibility of intervention of the legislature in terms of limiting the exercise of fundamental rights only in those situations where reconciling certain imperative interests must be done without affecting the substance of neither of them. Measures to restrict the exercise of certain rights may be taken either to prevent certain situations or to counteract or limit or prevent the spread of their negative consequences.

We note that, in the case of art. 53, one of the cases listed exhaustively and expressly include national security because the state of balance and social peace can be ensured only by a proportional adaptation of the rules of social coexistence with the threats, vulnerabilities and risks to the existence and development of the state. Thus, we find that even for this reason, in some situations, we can use art. 53 without necessarily resorting to the state of emergency (CCR Decision no. 1414/2009).

The state of emergency, although it contains elements of art. 53 of the Constitution, is established not by an act of the Parliament, but an act of the executive power. The reason for wishing to grant this attribution to the Head of State is the urgent and vital nature of the cause for which it is established. Also, the state of emergency untimely, unexpectedly suspends the exercise of some fundamental rights that we are used to exercising daily. And from this point of view, it differs from the restriction regime from art. 53 (where the citizen knows in advance the intention

${ }^{31}$ C. Dissescu, Dreptul constituțional, $3^{\text {rd }}$ edition, Bucharest 1915, p. 481, apud A. Iorgovan, Tratat de drept administrativ, vol. I, ALL Publishing House, Bucharest, 2005, p. 318.

${ }^{32}$ L. Barac, Inconsecvențe jurisprudențiale relative la posibilitatea restrângerii exercițiului unor drepturi sau libertăți fundamentale. Problematica limitării exercițiului unor drepturi și libertăți fundamentale în contextul instituirii stării de urgență sau a stării de alertă (I), juridice.ro, 19.05.2020, available at: https://www.juridice.ro/683898/inconsecvente-jurisprudentiale-relative-la-posibilitatea-restricting-the-exercise-offundamental-rights-or-freedoms-problematic-limiting-the-exercise-of-fundamental-rights-and-freedoms.html, accessed on 08.02.2021. 
of the legislator, the content of the legislative proposal/bill, the duration and extent of the effects of the restriction). Moreover, in the event of a state of emergency, Parliament plays only a role of approving (approving or rejecting the measure) the entire content of the decree, and could not make changes to the specific content of a restriction, as in the case of the law debated and adopted under the conditions of art. 53 (without the Parliament, of course, turning into an executive power that organizes practical execution of the law). All this physiognomy of defensive/offensive, alert, unexpected measure leads us to the idea according to which the Constituent wanted to create the institution of the state of emergency in order to defend a value as or more important than the rights whose exercise is restricted ${ }^{33}$. Or, what social value can be more important, if not one that defends the existence of the state and society as a whole?! In other words, we appreciate that the state of emergency seeks to prevent the occurrence and combat the evolution of phenomena that, once they produce their effects, affect the very existence of the state and the population. The state of emergency is not just a measure to restrict the exercise of certain rights, but also a set of measures aimed at increasing the country's resilience to certain types of dangers. The National Strategy for the Defense of the Country for the period 2020-2024 addresses this concept in two ways: "The inherent capacity of entities - individuals, communities, regions, states - to resist and adapt articulately to violent events, causing stress, shock, disasters, pandemics or conflicts, on the one hand, and the ability of these entities to return quickly to a functional state, of normality, on the other hand"34. The same strategy states that resilience covers all stages of a crisis, from prevention (when possible) to adaptation and mitigation (when necessary), and includes positive changes that strengthen the ability of current and future generations to secure their needs. This conceptualization reinforces our belief that the state of emergency is an institution meant to be activated only to prevent and combat the "very unlikely impact" 35 , i.e. that unexpected event, deeply destructive for citizens, the state and the values protected by the Constitution, and for which requires rapid, energetic measures adapted to the factual situation that generated them.

This conception of resilience is limited to the notion of national security, as it is described in art. 1 of Law no. 51/1991 regarding the national security of Romania and in the specialized doctrine. Unfortunately, because Law no. 51/1991 is a pre-constitutional one and the meaning of national security was related to the problems faced by the states in 1991, the degree of comprehension of the notion is not anchored to current realities, nor has constitutional jurisprudence been generous with an extensive interpretation of the concept, as we shall see below.

${ }^{33}$ N.C. Lazar, States of Emergency in Liberal Democracies, Cambridge University Press, Cambridge, 2009, p. 81.

${ }^{34}$ NSND 2020-2024, para. 41.

${ }^{35}$ N.N. Taleb, Lebăda neagră - Impactul foarte puțin probabilului, Curtea Veche Publishing House, Bucharest, 2018. 
The communist constitutions provided the state security as a fundamental reason, along with public order and national defense, for the institution of an exceptional measure (state of necessity, state of siege or war). However, the 1965 Constitution included both reasons of public order, along with those related to state security, within the scope of the "state of necessity". This Constitution also offers an important value to national security in the constitutional architecture, it being a frequently found institution, with strong connections related to the fundamental elements that define the Romanian state. The infra-constitutional legislator understood the importance he must give to the idea of defending the Constitution, or defending the fundamental elements that make up the state (territory, population, sovereignty). Defense is on one hand, ensuring the existence of these elements and, on the other hand, maintaining a balance, a state of legality and social peace to ensure development of the rule of law, constitutional democracy and the protection system of human rights. Although it may seem abstract, national security defends every value recognized and guaranteed by the Constitution, every right, every authority, ultimately forming the common goal of defending the existence of the state itself. From this perspective, national security is also the instrument through which the Constitution itself is protected.

In support of the special and strict framework in which the state of emergency can be established, art. 15, para. (1) of the European Convention of Human Rights, which states that "In the event of war or other public danger threatening the life of the nation, any High Contracting Party may take measures derogating from the obligations provided in this Convention, to the strictest extent required by the situation provided that such measures do not conflict with other obligations under international law". Thus, the temporary suspension of the application of the Convention by the Member States can be made only for reasons of national defense and national security, being the only cases accepted by the specialized doctrine ${ }^{36}$ whose danger "threatens the life of the nation". Implicitly, the European Convention urges Member States to build and exercise the institution of a state of emergency also for such reasons, and not others. For other reasons such as criminal investigation, public health or calamities, most ECHR member states have a constitutional system similar or identical to that provided by the Romanian Constitution in art. 53 by which the exercise of fundamental rights and freedoms may be restricted, in an ordinary climate of exercising state power.

On the occasion of the revision of the Romanian Constitution in 2003, the Government proposed to the Constituent Assembly the inclusion of an amendment in the Constitution by which, by organic law, the management of the state of siege and state of emergency, as well as other types of crisis shall be regulated. The amendment was rejected by the Constituent Assembly for the reason that "management is

${ }^{36}$ C. Bîrsan, Convenţia europeană a drepturilor omului. Comentariu pe articole, $2^{\text {nd }}$ edition, C.H. Beck Publishing House, Bucharest, 2010, pp. 979-982.

CONSTITUTIONAL LAW REVIEW 
involved in the state of siege and the state of emergency, and other types of crisis, such as a strike or an economic crisis, cannot be assimilated with the regime of such types of states and it is necessary to be managed under the normal regime, by usual means for their prevention and control' ${ }^{37}$. Thus, it was avoided to allow, on the one hand, the widening of the scope of the causes for which the state of emergency can be established and, on the other hand, the inclusion of new types of exceptional states. Reality has shown us that some exceptional states, such as the state of alert, have been instituted exclusively by law and present as causes of establishment similar to those in the sphere of constitutional democracy or national security specific to the state of emergency. We notice that, according to art. 41 of GEO no. 21/2004, the state of alert is established for "the prevention and removal of imminent threats to life, human health, the environment, important material and cultural values or property". Although the legislator wanted to create a fraud in the Constitution, bypassing the institution of the state of emergency through a similar one, but established by the Government, the Constitutional Court sanctioned this behavior and established, in Decision no. 157/2020, that the provisions of art. 4 of the GEO are constitutional insofar as the actions and measures ordered during the state of alert do not aim at restricting the exercise of certain fundamental rights or freedoms. The Court also found that the delegated legislator cannot in turn delegate to an administrative authority/entity what he himself does not have in his jurisdiction. Last but not least, in Decision no. $457 / 2020^{38}$, the Court emphasized that "Building' a new institution by law - the 'state of alert', with an obviously less restrictive regime than the state of emergency regulated by the constituent legislator - but allowing the circumvention of the constitutional framework that governs the legality, the separation of powers in the state, the conditions of restricting the exercise of certain rights and freedoms, contradicts the general requirements of the rule of law, as enshrined in the Romanian Constitution".

According to GEO no. 1/1999, the President of Romania is required, before the establishment of the state of emergency, to identify concretely the causes of its triggering, or those events that would fall within the notion of national security or calamity. If the causes are some concerning national defense, the President will establish a state of siege. The emergency order does not provide for an exhaustive, non-indicative case that could harm national security, constitutional democracy, national defense or any kind of calamity. So far, the President returns to look beyond the individual concepts in special legislation or policy documents such as National Strategy of National Defense (NSND) for the period 2020-2024. In the case of a state of emergency, we have previously shown that the notion of constitutional democracy involves several components such as the separation and balance of powers, national sovereignty, political pluralism or the system of protection of fundamental rights and

\footnotetext{
${ }^{37}$ Available at: http://www.cdep.ro/proiecte/2003/200/20/7/rp227.pdf, p. 21.

${ }^{38}$ CCR Decision no. 457/2020, from the Official Gazette, Part I, no. 578 of July 1, 2020, par. 68.
} 
freedoms. For each of these components, the state of emergency can be established if the event that generates it affects these categories, regardless of the intensity and its effects. In the matter of calamities, we remind that the notion is defined by art. 2, let. j) of GEO no. 21/2004. The legislation defining and listing cases of calamity allows the establishment of a state of siege for situations that do not involve measures such as the immediate restriction of the exercise of certain rights and the establishment of an exceptional situation. If the legislator wanted to give the calamities an importance worthy of taking measures specific to the state of emergency, they should have included them under the same umbrella of national security, especially since, in the last 3 national defense strategies, the calamities are presented as risks to national security. Therefore, in the current form of GEO no. 1/1999, due to the fact that they are highlighted separately, the calamities are not seen as affecting either national security or constitutional democracy, but they are still likely to cause the establishment of a state of emergency. In relation to the importance that the constituent and even the legislator gave to the state of siege, we appreciate that the events that can represent calamity and, therefore, the generation of an exceptional regime, are disproportionate and incorrectly regulated in GEO no. 1/1999.

In case of establishing a state of emergency for reasons of national security, the report proportionality on its establishment is evaluated based on threats, risks and vulnerabilities to national security, these being the elements according to which it is evaluated if a problem is or not of national security ${ }^{39}$. In Romania, there is also a normative consecration of these concepts, defined in NSND 2020-2024, at point 116 of the Strategy.

The Romanian legislator gave a dedication to the concept of law only to the notion of threat, which is seen from the internal perspective (internal factors triggers confused by vulnerabilities) and external (external factors triggers) art. 2 of Law no. 51/1991 on national security. Art. 3 of the same law expressly and exhaustively lists the categories of threats to national security, being the only reasons for which, for example, specific information collection activities may be ordered to restrict the exercise of fundamental rights and freedoms (CCR Decision no. 55/2020, para. 14).

By Decision no. 91/2018, the Court considered that the purpose for which the specific activities undertaken in the field of national security are used is different from that of the activity in the criminal process, therefore of the common regime of restricting the exercise of certain rights and freedoms. The Court considers that the first ones focus only on the knowledge, prevention and removal of internal and external threats in order to achieve national security. The constitutional court also

${ }^{39}$ H.G. Brauch, Security Threats, Challenges, Vulnerability and Risks, in H.G. Brauch, International Security, Peace, Development and Environment, vol. I, Otto-Suhr Institute for Political Science, Free University of Berlin, Germany, 2010; A.-N. Popa, Informaţiile clasificate şi societatea civilă. Protecția informațiilor clasificate prin intermediul protocoalelor, 2018, pp. 7-8, available at: https://www.academia.edu/37530510/Informa\%C5\% A3iile_clasificate_\%C5\%9Fi_societatea_civil\%C4\%83.Protec\%C8\%9Bia_informa\%C8\%9Biilor_clasificate_prin_int ermediul_protocoalelor.docx, accessed on 08.02.2021.

CONSTITUTIONAL LAW REVIEW 
indicated that there is a distinction between constitutional rights individually and collectively affected by a threat, only the latter being able, under certain conditions, to be the subject of national security interest ${ }^{40}$. Finally, the Court has defined what can and should look like threats to national security, contradicting the first argument with distinguishing between individual damage or collective rights, saying both may be subject to threats if properly and clearly defined by law ${ }^{41}$.

The Constitutional Court, also by Decision no. 91/2018, found that the phrase "seriously infringe the fundamental rights and freedoms of Romanian citizens" contained in Article 3, letter f) of Law No. 51/1991 on the national security of Romania is unconstitutional. The Court forces a distinction between individual and collective rights and freedoms that are pointless to criticize, from the fact that constitutional jurisdiction can't determine what constitutes a threat to national security, thus overcoming the competence offered by the Constitution. The State, through its executive, autonomous administrative and judicial authorities, has a positive obligation to guarantee all the rights and freedoms of Title II of the Constitution, whether individual or collective. The purpose of the intelligence services is also that of defending the constitutional values, aspect reflected even in Law no. 51/1991 and Law no. 14/1992.

By CCR Decision no. 802/2018, the phrase "other such interests of the country" from art. 3, let. f) of Law 51/1991 is declared unconstitutional due to lack of clarity, predictability and quality ${ }^{42}$. Article 3, let. f) of Law no. 51/1991 states as threats to the national security of Romania acts such as undermining, sabotage or any other actions aimed at forcibly removing the democratic institutions of the Romanian state or which seriously infringe the fundamental rights and freedoms of Romanian citizens or actions that may impair the ability of defense or other such interests of the country. Any acts of destruction, degradation or rendering in a state of non-use of the structures necessary for the good development of the socio-economic life or the

40 "The legislator must make a distinction between acts which seriously infringe the fundamental rights and freedoms of citizens and which may be classified as matters of criminal law, with the consequence that the means of criminal law and criminal proceedings, on the one hand, and those acts that are directed against the rights and freedoms of a collectivity/community (race, ethnic origin, religion etc.), which, by the number of individuals belonging to it, determine the extent of the acts directed against it, and may pose a threat to security on the other hand."

41 "In order to be seen as threats to national security, actions/facts must be directed either against an individual subject or against a collective subject."

$42 "(. .$.$) the scope of the phrase 'other such interests of the country remains at the discretion of the body$ empowered to apply the law, without being able to be circumstantial by the recipient of the rule. Thus, by correlating between the form/manner of manifestation of the activities provided by art. 3 let. f) of Law no. 51/1991 with the aim pursued/the value harmed by that activity, in this case the possibility of reaching the 'other interests of the country, the limit of application of the criticized law provision can no longer be determined. The open nature of the criticized phrase determines the possibility of introducing or excluding elements in/from this category, an action that also affects the limits of application of the criticized legal provision. In this way, the limits of application of the criticized provision of law can no longer be known by the addressees of the norm, who, thus, cannot correct their conduct and cannot be able to foresee, to a reasonable extent, the consequences that may arise from a certain act."

STUDIES AND ARTICLES 
national defense of Romania are also provided. From a systematic interpretation of literary text and "such other interests of the country", that it follows a specific enumeration of types of threats and "undermine, sabotage or any other actions" aimed at (1) removing by force the democratic institutions of the state", (2) which seriously infringe the fundamental rights and freedoms of the Romanian citizens and (3) which infringe the country's defense capacity. The legislator thus starts a list of national security interests, hereinafter referred to as "other such interests". We appreciate that the legislator, when he referred to this phrase, made reference to the National Strategy of National Defense, according to Art. 1, par. (1) and of art. 4, par. (3), lit. a) of Law no. 203/2015 on defense planning, must provide for "Romania's national security interests". Moreover, in NSND 2020-2024, in Chapter II, the national security interests are provided, the 3 expressly mentioned in Law no. 51/1991 being found among them. This reinforces the reasoning that the phrase declared by the CCR as unconstitutional was not lacking in predictability, quality and clarity, but referred to another legal norm of primary force which establishes in the NSND the enumeration of national security interests which, given the dynamic and adaptable, changes from one cycle to another ${ }^{43}$.

Finally, by declaring the phrase unconstitutional, the CCR decides iure et de iure that actions against (1) guaranteeing the national character, sovereignty, independence, unity and indivisibility of the state, (2) capitalization of resources and strategic positioning of our country in order to achieving the level of well-being to which citizens are entitled, (3) reducing the development and reconstruction gaps of large public systems, (4) ensuring the irreversibility of belonging to the transatlantic collective defense system and (5) strengthening the European Union and active participation in the integration processes within it do not represent threats to Romania's national security. The Court denies its own jurisprudence (Decision no. 148/2003 ${ }^{44}$ ) in which it recognized that, for example, "Romania's desire to join Euro-Atlantic structures is legitimized by the country's interest", so it is a matter of national security.

Another problem that the Court creates is that it presumes that national security is a plurivalent concept (par. 71) and that it cannot have an all-encompassing and abstract definition. This statement even denies art. 1 of Law no. 51/1991 which defines the national security of Romania. By classifying this presumption as absolute, the Court arrives at another absolute presumption that neither the notion of "interest of the country" doesn't have a legislative definition, or a constitutional one, although Law no. 203/2015 defines the interests of national security. Moreover, the Constitution itself speaks of the "national interest" [art. 87, para. (1) and art. 90, art. 135, para. (2), letters b) and d) and art. 136, para. (3)]. The CCR decision thus raises the question of whether "securitization" (the introduction of a field in the field

${ }^{43}$ A.N. Popa, Lawfare - nouă confruntare hibridă care a cucerit România, presented at the student scientific Conference "Intelligence și Cultura de Securitate - 2020", 15.06.2020, Bucharest, ANIMV.

${ }^{44}$ CCR Decision no. 148/2003, published in the Official Gazette, Part I, no. 317 of May 12, 2003. 
of national security) can still be done by administrative acts (CSAT or NSND decision) or only by law (formally as an act of Parliament and material as GEO).

In conclusion, following several CCR decisions, the limits of national security, from the perspective of the types of threats, restrict the margin of appreciation of the legislator and the head of state when they want to regulate or institute a state of emergency for such reasons. Currently, the President is limited, when establishing the state of emergency for reasons of national security, to see the extent to which the cause of establishment falls under the scope of art. 3 of Law no. 51/1991 and if it falls within the concept established by the Constitutional Court in its jurisprudence, an insufficient limitation related to the real and current security problems Romania is facing.

\section{Is a pandemic a national security issue?}

On March 16, 2020, the President of Romania instituted a state of emergency throughout Romania. Analyzing the content of the founding decree, several problems are found. In the first, the decree does not stipulate the reasons for establishing the state of emergency (national security, constitutional democracy or calamity), but invokes the entire article 3 of GEO no. 1/1999 which includes all three. Seeing the meaning of the notion of "calamity" in art. 2, let. j) of GEO no. 21/2004 and that of constitutional democracy (which sometimes may be of interest to national security), we consider that a pandemic can't fit into these concepts, the state of emergency remaining to be imposed only for reasons of national security. Secondly, the President did not state in the preamble to the decree the facts and the legal basis for which a pandemic could be a matter of national security. In fact, the preamble presents only a series of facts that describe the evolution of the pandemic, not related to any text of law to give them legal valence. Facts described it implied even that we had in the event of disasters, seen as a natural phenomenon (community transmission, on a global scale, a virus) that could increase mortality so much that it can affect the proper functioning of the state or relations between citizens. Although the negative impact of the virus on current social relations cannot be denied, its effects must have been set out in detail in the founding decree and linked to a legal rule setting out the cause of the condition.

As we have seen, Law no. 51/1991 and the jurisprudence of the CCR limit the areas that may be of interest for national security. If, in the past, the CCR even defined the concept of security extended in Decision no. 872/2010, admitting the idea of securitizing the Socio-Constructivist School in Copenhagen and used in most countries of the world in national security and defense strategies (see US National Intelligence Strategy $2019^{45}$ ), by CCR Decision no. 26/2019, also CCR criticized and

${ }^{45}$ National Intelligence Strategy of the United States of America, 2019, available at: https://www.dni.gov/ files/ODNI/documents/National_Intelligence_Strategy_2019.pdf, accessed on 14.03.2021.

STUDIES AND ARTICLES 
limited the concrete ways in which, illegally, new areas are brought in the sphere of interest of national security.

Thus, even if NSND 2020-2024 considers pandemics as threats to national security, the notion is not found among the threats provided by art. 3 of Law no. 51/1991. In this respect, the National Defense Strategy far exceeds the legal framework in which the types of threats can be defined, at least from the perspective of the Court, even if Law no. 415/2002 and Law no. 203/2015 allow the establishment of new threats through NSND. In this case, due to the jurisprudence of the CCR that demands a security removal of the fields that are not provided by art. 3 of Law no. 51/1991, a pandemic cannot constitute a threat to national security for which to establish measures such as the state of emergency.

The field of human health can no longer be a matter of interest for national security, because, following the CCR Decision no. 91/2018, the phrase "seriously infringe the fundamental rights and freedoms of Romanian citizens" is unconstitutional. This phrase brought into the sphere of national security all those fundamental rights and freedoms recognized by the Constitution (including art. 34), as some extremely important for the existence of the Romanian state. Moreover, even at the level of the Romanian Intelligence Service there is a direction of "Defense of the Constitution" which has as attributions also the prevention and combating of threats to the rights and freedoms provided in Title II of the Fundamental Law. With the declaration of the phrase as unconstitutional, public health, as well as education, the protection of children and young people or the right to free movement, are no longer of interest for national security. However, the field of "public health", which is distinct from that of individual health of persons, may be subject to the restriction of the exercise of certain rights and freedoms being included in the areas expressly listed by art. 53 of the Constitution. However, for a person's individual health and public health to become of national security interest, the legislator should amend art. 3 of Law no. 51/199 and to articulate as tangible the acts and facts that may threaten individual and public health.

In view of the above considerations, we find that, in the present case, a pandemic or a health problem of the person or the public, no matter how serious, cannot constitute causes of establishing a state of emergency for reasons of national security, if they do not fall under the incidence of art. 3 of Law no. 51/1991. In this context, the NSND 2020 -2024, which states public health and a pandemic as security issues, appears to lack legal relevance and practical applicability in terms of establishing measures that restrict the exercise of fundamental rights and freedoms.

\section{Conclusions and recommendations}

The state of emergency is not only an exceptional measure restricting the exercise of fundamental rights and freedoms, but a defensive/offensive, rapid reaction that temporarily suspends the exercise of certain rights, the normal 
functioning of fundamental institutions and the normal exercise of human rights. It occurs in a specific framework for profound social disorder, of imminent threats, as opposed to restricting exercised in art 53. Therefore, it needs to be instituted for other cases than the ordinary ones from art. 53 and to protect values and rights at least equal to those it violates. We consider that ensuring the existence of the state (seen as territory, population and sovereignty) and the security of the population (seen as a community) are necessary and sufficient elements to be protected from the state of emergency, being the starting point from which to analyze whether a situation imposes or not the establishment of the state of emergency. When we talk about defending the existence of the state, or the constitutional order and the Constitution itself, we are talking about national security, national defense and public order. For the national defense exists a remedy of the state of siege and for the public order there are the solutions from art. 53. Therefore, national security should be the only reason for which such an exceptional regime of state of emergency can be established, which comes by fast means, by force, to restore the state of balance, legality, social peace.

The problem, at the infra-constitutional legal level, place limits on national security, which, as we have seen, are expressly and exhaustively provided amenities of art. 3 of Law no. 51/1991 and whose method of regulation is harshly criticized by the CCR. The Law no. 51/1995 is a pre-constitutional one and does not meet current security needs and is designed in a time when the notion of security had other meanings in this geopolitical space. In a world in which threats, vulnerabilities and risks to the state are increasingly dichotomous, unconventional and asymmetrical currently in Romania, it gets harder for us to update and to legally recognize, being forced to adopt laws in this sense. This reality can be seen from a double perspective. The first is that the regulation of threats, by law, guarantees the proper exercise of fundamental rights and freedoms and that the CCR wanted to give precedence to these rights over the idea of security. The second approach is that we can find that restricting ourselves alone just by law new types of threats, we can be faced with the inability of reacting quickly to those issues that do not expect the Parliament to legislate them. The COVID-19 pandemic was one of those cases in which, although it "enjoyed" the state of emergency regime, it can be seen that the establishment of the state did not have an adequate constitutional basis and no well-regulated infra-constitutional legal regime. Maybe even for this reason, totally unjustified, moreover, the legislator chose to find a solution through the establishment of a new exceptional state, state of alert, through which to take, currently, those measures to combat the COVID-19 pandemic.

Finally, it is up to the infra-constitutional legislator to regulate the limits for which the state of emergency can be established, but also the scope of the notion of threats to national security, so that the measures taken by the state are proportionate to guaranteeing citizens' rights, but also satisfy the collective and individual need for security in the face of the new problems that states and citizens face.

STUDIES AND ARTICLES 